\title{
REITER'S SYNDROME AND CORTISONE
}

\author{
BY \\ H. A. REID \\ General Hospital, Penang, Malaya
}

(RECEIVED FOR PUBLICATION FEBRUARY 24, 1954)

The three main features of Reiter's syndrome are conjunctivitis, polyarthritis, and urethritis, although the patient described by Reiter (1916) also had diarrhoea. The vast majority of reported cases have been seen in young adult males. It is thought that the following case may be of interest because the patient was an elderly female and her response to cortisone was disappointing.

\section{Case Report}

A Eurasian widow, aged 62, was admitted to the General Hospital, Penang, on November 5, 1952, with a history of 9 days' fever and dysuria followed by sore eyes and severe pain in the left wrist. For the previous 20 years she had been subject to attacks of "rheumatism". She described this as intermittent pains in the feet, knees, and back, lasting a few days or weeks but not accompanied by any joint swelling. The upper limbs were not affected. The "rheumatism" had not necessitated staying in bed. She had never suffered from dysentery. Nine days before admission there had been a sudden onset of "fever" with dysuria. The patient noticed "blood and pus" in the urine and this was confirmed by her family doctor. After 4 days, her eyes became sore and the left wrist painful, red, and swollen. During the next few days the dysuria gradually stopped but the severity of the other symptoms increased.

On admission, she appeared to be an intelligent woman obviously ill. She weighed $56 \mathrm{~kg}$. The temperature was $100 \cdot 2^{\circ} \mathrm{F}$. She had purulent conjunctivitis, and there was marked tenderness and limitation of movement, with swelling, redness, and increased heat of the left wrist and first metacarpophalangeal joints. Physical examination was otherwise not remarkable. There was no vaginal or urethral discharge. No skin lesions, lymphadenopathy, or splenomegaly were observed. Urine examination showed many pus cells but culture was sterile.

Blood Examination.

No malaria parasites;

Haemoglobin, 65 per cent.;

Leucocytes, 14,600 per c.mm. with normal differential count;

Sedimentation rate (Westergren), $107 \mathrm{~mm}$./hr;

Uric acid, 3.6 mg. per cent.;

Kahn test negative.

Thereafter serial leucocyte counts were within normal limits.
During the next 3 weeks she was given penicillin eye drops, sulphatriad (total $20 \mathrm{~g}$.), and sodium salicylate (6 g. daily). After a week her conjunctivitis and pyuria had cleared up but the general condition and arthritis became worse. Pyrexia continued, her weight fell by $2 \mathrm{~kg}$., and the arthritis spread to the joints of the left fingers and elbow, right thumb, wrist, knees, and toes, with, in most joints, marked tenderness, limitation of movement, swelling, increased heat, and redness. $X$ rays of chest, wrists, and fingers showed no abnormality. Sodium salicylate was increased to $12 \mathrm{~g}$. daily for 4 days with slight though definite decrease in arthritic manifestations.

On November 29 cortisone was started, $100 \mathrm{mg}$. twice daily, then $50 \mathrm{mg}$. twice daily by intramuscular injection. All other drugs were stopped. The cortisone was stopped on December 23 after $2.6 \mathrm{~g}$. had been given. During this $3 \frac{1}{2}$-week period there was a gradual improvement in her general and arthritic condition. She felt better and her appetite improved. The pain and swelling in many of the joints diminished. Objectively, however, the response was far from dramatic. Intermittent pyrexia continued, there was no gain in weight, and serial sedimentation rates consistently ranged above $100 \mathrm{~mm}$./hr. Moderate improvement in tenderness, swelling, and movement was noted in many joints, but in a few, these signs became more marked. After the cortisone was stopped, the arthritis again became worse, and within a week was much the same as when cortisone was started. She was given $3 \mathrm{~g}$. aspirin daily and weekly intramuscular injections of $50 \mathrm{mg}$. myocrysin (total, $320 \mathrm{mg}$.). During 3 weeks of this regime, there was no significant change. On January 13, 1953, the daily dose of aspirin was increased to 8 g., but after 3 days it was reduced to $4 \mathrm{~g}$. on account of vomiting and tinnitus.

Thereafter, there was a gradual but consistent improvement. She became afebrile, and on February 7 , her only complaint was slight pain in the wrists. The blood sedimentation rate was still above $100 \mathrm{~mm}$./ hr. The dosage of aspirin was reduced and she was discharged from hospital on February 18, when there was moderate thickening and limitation of movement of both the left wrist and the left elbow joint. On July 9, 1953, she felt quite well apart from occasional twinges of pain in wrists and fingers, and had resumed her occupation of sewing to supplement her income. She weighed $58 \mathrm{~kg}$. and looked well. There was full painless movement 
of all joints and slight thickening of the left wrist. The B.S.R. was $50 \mathrm{~mm}$./hr. $X$ ray of wrists and fingers was again normal.

\section{Comment}

The cause of Reiter's syndrome is not known. Dysentery and a venereal aetiology have both been suggested, but both can be confidently excluded in the case reported. As the disease is generally selflimiting, the effects of treatment are difficult to assess. Ogryzlo and Graham (1950) described three cases as responding dramatically to ACTH (40 and $100 \mathrm{mg}$. daily) and cortisone (one course by injection totalling $4.4 \mathrm{~g}$. in 23 days, later an oral course of $3.5 \mathrm{~g}$. in 17 days). Joint pain and tenderness disappeared within 3-10 days. The B.S.R. fell to normal in two cases, and from 110 to $39 \mathrm{~mm}$./ hr in the third. On withdrawal of hormones, relapse was rather prompt in all cases, although the returning symptoms were usually not so severe and the subsequent course was one of improvement. Evang (1952) was not so enthusiastic; she reported a case in which cortisone was administered intramuscularly for 6 weeks (total 5 g.). There was a definite decrease in joint pain and swelling, but slight pain persisted. The joint symptoms recurred after discontinuation of cortisone but were not as severe as before the treatment. She concluded that cortisone did not have any certain effect on the duration of the disease.

In the case reported above, the response to cortisone did not appear to differ significantly from the response to aspirin, and in view of the natural history of the syndrome, it is doubtful if either drug had any effect on the disease.

Kellgren and others (1952) reported cases of rheumatoid arthritis which responded only partially or not at all to cortisone. Three patients had withdrawal deterioration although administered hormone had had no apparent effect.

Subsequently, Kersley and others (1952) published a case in which lack of response to cortisone could not be explained by inadequate dosage, failure to reach the target organ, or lack of conversion to hydrocortisone, and the fault was presumed to lie primarily in the end-organ or affected tissues.

\section{Summary}

A case of Reiter's syndrome in an elderly woman is reported. The observed response to cortisone was poor.

I wish to thank the Director of Medical Services, Malaya, for permission to publish this paper.

\section{REFERENCES}

Evang, E. (1952). Nord. Med., 47, 123.

Kellgren, J. H., Janus, O., Moore, R., and Jackson, D. S. (1952). Brit. med. J., 1, 997.

Kersley, G. D., Mandel, L., and Desmarais, M. H. L. (1952). Ibid., 2, 540 .

Ogryzlo, M. A., and Graham, W. (1950). J. Amer. med. Ass.,

Reiter, H.'(1916). Dtsch. med. Wschr., 42, 1535.

\section{Syndrome de Reiter et Cortisone}

RÉSUMÉ

On rapporte un cas de syndrome de Reiter chez une femme âgée. On observa que la reponse à la cortisone fut faible.

\section{Sindrome de Reiter y la cortisona}

\section{Sumario}

Se relata un caso de síndrome de Reiter en una mujer de edad avanzada. Se observó que la respuesta a la cortisona fué escasa. 